\title{
European Accreditation of Public Health Education
}

\author{
Robert Otok, MPH, ${ }^{1}$ \\ Ilana Levin, MPH, ${ }^{1}$ \\ Stojgniew Sitko, $\mathrm{PhD},{ }^{2}$ \\ Antoine Flahault, $\mathrm{MD}, \mathrm{PhD}^{1,3}$
}

\begin{abstract}
The European Agency for Accreditation in Public Health Education (APHEA) was launched in 2011. This followed nearly two decades of efforts in a variety of programmes supported by international donor agencies, and others that provided experience and field testing of peer review systems for schools of public health in Europe. The Association of Schools of Public Health in the European Region (ASPHER) Public Health Education European Review (PEER) project, devised with the aid of WHO EURO in the early 1990s and later by the Open Society Institute (OSI) within the framework of a joint ASPHER-OSI Program from 20002005 , helped to develop a cadre of expertise on the process of international peer review and standards that are compatible with a full accreditation process.

The purpose of this paper is to provide a brief overview of the background, criteria and current pilot phase of European accreditation for the Master of Public Health degree and equivalent study programmes. Undergoing the accreditation process will help longstanding and new schools review their programmes to meet new European accreditation system standards and provide students, graduates and potential employers with confidence in the future acceptability of their credentials. The new accreditation agency was established by a consortium of European public health organisations and represents a new phase for development of standards and quality of education systems in Europe to face the challenges of workforce development for a "New Public Health" era in the $21^{\text {st }}$ century.
\end{abstract}

Keywords: Accreditation, public health education, Europe

Recommended Citation: Otok R, Levin I, Sitko S, Flahault A. European Accreditation of Public Health Education. Public Health Reviews. 2011;33:30-8.

\footnotetext{
${ }^{1}$ Association of Schools of Public Health in the European Region (ASPHER), Brussels.

${ }^{2}$ Institute of Public Health, Jagiellonian University, Krakow.

${ }^{3}$ EHESP French School of Public Health, Paris and Rennes.
}

Corresponding author contact information: Ilana Levin at Ilana.Levin@ehesp.fr 


\section{INTRODUCTION}

For many years, the Association of Schools of Public Health in the European Region (ASPHER) has been a key participant in initiatives to establish an organised system of accreditation for public health education in Europe. ${ }^{1}$

In 2008/2009, the Association conducted a strategic planning process through a three round Delphi study. One of the highest priorities of ASPHER members, which emerged from this consultation process, was the establishment of a European accreditation system for Master of Public Health (MPH) programmes. This led to the appointment of an ad hoc Working Group on Accreditation to prepare the launch of this system. Finally, in 2011, thanks primarily to the determination of some key individuals and exactly a decade after a clear indication from ASPHER members on the desired direction for the process at the deans' retreat in Magdeburg in May 2001, ASPHER made historical progress which it had been working towards for so long- the long-awaited Accreditation Agency for Public Health Education was launched on April $1^{\text {st. The founding }}$ consortium of the new system consists of the following prominent European public health organisations: ASPHER, the European Public Health Association (EUPHA), the European Public Health Alliance (EPHA), the European Health Management Association (EHMA), and EuroHealthNet.

\section{BENEFITS OF A EUROPEAN ACCREDITATION SYSTEM}

MPH programmes are at present evaluated or accredited by national education authorities in most countries within the European Region. However, there is presently no specific accreditation system for education in public health either at the transnational or regional level in Europe. An independent international (or transnational) accreditation system, in accordance with the Bologna Process, brings important added value as far as benefitting students and academics, and recognising a school's quality beyond the borders of its home country.

Establishment of the European system will help many institutions improve the quality of their programmes and raise their profile, thereby aiding them in their ongoing planning and negotiations with national authorities to obtain financing, not only for teaching and learning, but also for research and advocacy activities. It will also bring greater academic recognition to faculty and staff members, thereby assisting them in seeking grants from sources such as the European Union. 
A degree from a European accredited programme potentially provides the graduate with improved opportunities for employment internationally and allows for transferability of qualifications. It also benefits foreign students who may wish to study in a particular country and will be able to bring home an internationally recognized degree. The mark of accreditation may thus increase a programme's attractiveness to national as well as foreign students. In addition, accreditation by an international organization will assure employers of the expected quality and competencies of potential employees. A programme accredited by national authorities alone, no matter how rigorously the accreditation process is carried out, still lacks the international recognition that a European accreditation system provides. European accreditation serves as an additional proof of standards and quality for students, academics, partner institutions, and funding bodies.

\section{HISTORY OF THE ACCREDITATION PROJECT}

In 1992, the ASPHER General Assembly gave a mandate to the Executive Board to organise a process that would take the lead in the following years in devising the Public Health Education European Review (PEER), as a voluntary initiative for institutions. At that time, the Board was divided between those who favoured a formal system of accreditation and those who preferred a more informal evaluation process intended to support schools. The latter was successfully advocated for based on the argument that there was too much variation between public health training offered in different countries and that if the benchmark was placed too high, only a few institutions would "pass", putting the Association in some difficulty; on the other hand, if the benchmark was placed too low, the process would be discredited for years to come. By 1999, 12 programmes were reviewed by PEER $^{2}$ and the question of evolving towards a formal accreditation system was again raised, but this time, within a slightly different context. The heads of all the PEER-reviewed institutions were generally satisfied with the process and outcome of the PEER process. Simultaneously, there was a growing expectation for more active development and standardisation of quality across programmes. The need for a formal accreditation system became more explicit and more widely accepted among members of ASPHER.

At the end of 1999, ASPHER and the Foundation Mérieux signed an agreement to carry out a collaborative project in 2000 and 2001 aimed at proposing a framework, based on international and ASPHER's own experience from PEER reviews, for the improvement of quality in public 
health training in Europe and eventual evolution towards accreditation of training programmes. At the annual retreat in Magdeburg, Germany on May 11-12, 2001, ASPHER deans and directors endorsed the recommendations made by an ad hoc group of experts for the association to initiate the development of an accreditation body. This included the directive that the accreditation body should be independent and should ensure representation of legitimate interests in public health. The results of this work were published in 2001 in a book as part of the Foundation Mérieux Collection with the title "Quality Improvement and Accreditation of Training Programmes in Public Health". ${ }^{3}$

Subsequently, the ASPHER Executive Board set up an Accreditation Task Force which, in the following year, developed the Accreditation Framework Document ${ }^{4}$ presented to the ASPHER deans and directors at the annual retreat in Saint Maurice, France on May 24-25, 2002. The PEER criteria and procedures were profoundly revised and enhanced within the context of the new framework. In December 2002, ASPHER and EUPHA signed a cooperation agreement for the furthering of the establishment of a European accreditation agency for public health training programmes. In October 2005, with support from the European Union funded European Master of Public Health (EMPH) Project, the Accreditation Task Force developed two additional documents - Accreditation Procedure Document $(\mathrm{APD})^{5}$ and Accreditation Standards and Requirements. ${ }^{6}$

Meanwhile, some European countries still did not have schools of public health or public health training programmes and did not incorporate many of the more modern tools of public health education and practice. This shortage in training capacity was felt particularly acutely in Central and Eastern European countries. A wide-reaching development programme funded from 2000-2005 by the Open Society Institute (OSI) and implemented by ASPHER was designed to respond to the region's need for public health training capacity. This was accomplished through: twinning and mentoring projects with already well-established schools of public health; on-site consultations; PEER reviews; and faculty training and development both in country and abroad. A book documenting the experience and lessons from this thirteen-country project was published in 2008, entitled "Public Health Workforce Capacity Building: Lessons Learned from Quality Development of Public Health Teaching Programmes in Central and Eastern Europe". ${ }^{7}$ Lessons learned from the OSI experience, as well as from PEER, were later transferred to the new European accrediting body. The OSI-ASPHER PEER project provided vital experience for the development of the agency and its processes, as it provided basic ideas, precedent and tools. ${ }^{8}$ 
The European Accreditation of Public Health Education Project (PH-ACCR) was an EU-funded project (Leonardo da Vinci funding programme) coordinated by Jagiellonian University Medical College, Institute of Public Health in Krakow, Poland. The PH-ACCR Project was started in November 2005 and ended in November 2007. Other partners included:

- School of Health and Related Research, University of Sheffield, United Kingdom;

- Faculty of Health Sciences, University of Maastricht, The Netherlands;

- National School of Public Health, Rennes, France;

- Institute of Public Health, University of Copenhagen, Denmark;

- Faculty of Public Health, Medical University of Sofia, Bulgaria;

- EUPHA.

The main aim of this project was to develop standardisation and quality criteria with respect to public health education in Europe and to further test and institutionalise them in the form of a European Accreditation Agency for Public Health Education. The accreditation criteria/standards based upon the APD $(2005)^{5}$ were elaborated and grouped into a set of nine dimensions. ${ }^{6}$ Accreditation procedures and the structure of the proposed accreditation agency were agreed upon and drafted. ${ }^{9}$ These documents together with the completed Report on Quality Assurance and Accreditation Systems in Public Health Education ${ }^{10}$ formed part of the future accreditation system description. Based upon these foundations, a pilot accreditation system was proposed, and a search procedure for accreditation experts was commenced following the Project Conference in Copenhagen, Denmark in December 2006. Two MPH programmes (Sheffield and Kaunas) underwent a pilot accreditation review in spring of 2007. The Project Conference that took place in Krakow on November 29-30, 2007, was the final event of the project.

It was another two years before an ASPHER Working Group was created, once again for the purpose of re-assessing the eligibility criteria for accreditation, accreditation standards, and procedures created during the Leonardo Project and building a consortium with key European partner non-profit public health organizations in order to launch the new agency. The European Agency for Public Health Education Accreditation (APHEA) was launched on April 1 1 ${ }^{\text {st }}, 2011$ in Brussels, Belgium in the presence of representatives of all partner organisations as well as numerous representatives of schools interested in undergoing accreditation in the near future. 


\section{THE NEW ACCREDITATION SYSTEM}

Membership in the APHEA Board of Directors includes representatives from all five partner organisations (ASPHER, EUPHA, EPHA, EHMA and EuroHealthNet), while guidelines require that the chair of the Board of Accreditation is an individual highly distinguished in the field, but not directly associated with any of the organisations in the consortium.

Table 1

Core subject domains to be included in MPH Curricula as required by APHEA

\begin{tabular}{|c|c|c|}
\hline $\begin{array}{l}\text { Core Subject } \\
\text { Areas }\end{array}$ & Curriculum Content & $\begin{array}{l}\text { ECTS* } \\
\text { Credit } \\
\text { Ranges** }^{*}\end{array}$ \\
\hline Introduction & Introduction to public health & 2 \\
\hline $\begin{array}{l}\text { Methods in public } \\
\text { health }\end{array}$ & $\begin{array}{l}\text { Epidemiological methods, biostatistical methods, } \\
\text { qualitative research methods, survey methods }\end{array}$ & $18-20$ \\
\hline $\begin{array}{l}\text { Population health and } \\
\text { its determinants }\end{array}$ & $\begin{array}{l}\text { Environmental sciences (including physical, chemical } \\
\text { and biological factors), communicable and non- } \\
\text { communicable disease, occupational health, social and } \\
\text { behavioural sciences, health risk assessment, health } \\
\text { inequalities along social gradient }\end{array}$ & $18-20$ \\
\hline $\begin{array}{l}\text { Health policy, } \\
\text { economics, and } \\
\text { management }\end{array}$ & $\begin{array}{l}\text { Economics, healthcare systems planning, organisation } \\
\text { and management, health policy, financing health } \\
\text { services, health programme evaluation, health targets }\end{array}$ & $16-18$ \\
\hline $\begin{array}{l}\text { Health education and } \\
\text { promotion }\end{array}$ & $\begin{array}{l}\text { Health promotion, health education, health protection } \\
\text { and regulation, disease prevention }\end{array}$ & $16-18$ \\
\hline $\begin{array}{l}\text { Cross-disciplinary } \\
\text { themes } \\
\text { (mandatory and/or } \\
\text { elective courses) }\end{array}$ & $\begin{array}{l}\text { Biology for public health, law, ethics, ageing, nutrition, } \\
\text { maternal and child health, mental health, demography, IT } \\
\text { use, health informatics, leadership and decision-making, } \\
\text { social psychology, global public health, marketing, } \\
\text { communication and advocacy, health anthropology, } \\
\text { human rights, programme planning and development, } \\
\text { public health genomics, technology assessment }\end{array}$ & $21-23$ \\
\hline $\begin{array}{l}\text { Internship/final project } \\
\text { resulting in thesis/ } \\
\text { dissertation/memoire }\end{array}$ & Supervised by faculty (full time and/or adjunct) & $24-26$ \\
\hline
\end{tabular}

* European Credit Transfer and Accumulation System (or equivalent).

** The subject areas and credit ranges above are recommended; the accreditation process will assess the credit division among subject areas for a given programme.

Source: APHEA Eligibility Criteria. ${ }^{13}$ 
The curriculum required by APHEA is based on the core subject domains from the list developed in the European Public Health Core Competencies Programme, ${ }^{11,12}$ though slightly regrouped (Table 1).The agency adopted a fitness for purpose approach* to assess an academic institution based on the premise that an academic institution will set its mission for education and research within the context of a specific regional or national environment. This approach necessitates an orderly process on the part of the institution for developing programme aims, ongoing assessment to determine how well the aims are carried out, and guidance in using this information in directing and revising final qualifications, curriculum modules, strategies and operations. Ongoing assessment is meant to lead to programme improvement as part of the fitness for purpose approach. For purposes of determining conformity with APHEA accreditation criteria, the Board of Accreditation will consider current developments and planned changes as they relate to the fitness for purpose process. This approach takes into account the diversity of the European schools of public health, while at the same time setting a certain level of curriculum standards for high quality education and training in public health in Europe.

The Call for Commitment circulated to ASPHER members in October of 2010 indicated that there is great interest amongst ASPHER member institutions to undergo accreditation of their public health or equivalent programmes at the European level. The agency is starting with three accreditations in 2011 and hopes to reach a capacity of ten per year by 2013.

\section{SUMMARY AND CONCLUSIONS}

Over the years, ASPHER has led the way in developing a much-needed system of accreditation for public health education programmes in Europe. The PEER, OSI and PH-ACCR projects were necessary to set the stage and develop and test the process for the accreditation agency. The recent developments resulted in a situation in which the PEER and accreditation programmes are managed by two separate bodies. Whereas the PEER programme is managed by ASPHER, as it always has been-though it is currently becoming the core function of the newly established working group on mentoring schools of public health - the accreditation programme now constitutes an independent body.

\footnotetext{
* Fitness for purpose equates quality with the fulfilment of a specification or stated outcomes.
} 
From the outset this option was considered to be the most suitable as it allows ASPHER to remain in charge of quality improvement for its member institutions but at the same time ensures the independence of the newly founded accreditation body. This assures the credibility of APHEA and that in the future the agency will be approved by international agencies in charge of accrediting bodies and gain entry into international quality assurance registers.

The European accreditation process for MPH programmes is now under way. All participant organisations and individuals who contributed to this process are confident that this process will set new and improved standards for MPH training in Europe. This will ultimately help to improve the competencies and employability of those graduating from public health programmes and entering the workforce, thereby contributing to the advancement of the field of public health across the vast European region.

Acronyms list:

APD $=$ Accreditation Procedure Document

APHEA = the European Agency for Accreditation in Public Health Education ASPHER $=$ the Association of Schools of Public Health in the European Region EHMA $=$ the European Health Management Association

$\mathrm{EPHA}=$ the European Public Health Alliance

EUPHA $=$ the European Public Health Association

MPH = Master of Public Health

OSI $=$ the Open Society Institute

PEER = Public Health Education European Review

$\mathrm{PH}-\mathrm{ACCR}=$ the European Accreditation of Public Health Education Project

Conflicts of interest: None declared.

Acknowledgments: We would like to thank the great many people who contributed to the establishment of the new accreditation agency and to the earliest phases of its operation.

\section{REFERENCES}

1. Association of Schools of Public Health in the European Region. European Accreditation of Public Health Education Project. ASPHER. Available from URL: http://aspher.org/index.php?site=acc (Accessed 14 September, 2011).

2. Association of Schools of Public Health in the European Region. Procedures for the Public Health Education European Review (PEER). ASPHER. July 2001. Available from URL: http://www.aspher.org/pliki/pdf/procedures_for_the_ peer.pdf (Accessed 14 September, 2011).

3. Bury $\mathbf{J}$ et al. Quality improvement and accreditation of training programs in public health. Edition Foundation Merieux: Lyon; 2001. 
4. Sitko S, Adany A, Meulmeester J, Normand C, Magnusson G, Bury J, Cavallo F, Louvet T. Accreditation Framework. November 2002. Available from URL: http://www.aspher.org/pliki/pdf/accreditation_framework_document. pdf (Accessed 14 September, 2011).

5. Sitko SJ, Adany R, Garaedts M, Krasnik A, Louvet T. Accreditation of Public Health Education Programmes: Challenge in Quality Improvement for the Schools of Public Health of the European Region, Accreditation Procedure Document. October 2005. Available from URL: http://www.aspher.org/pliki/ pdf/accreditation_procedure_document.pdf (Accessed 14 September, 2011).

6. Association of Schools of Public Health in the European Region. Accreditation of Public Health Education: Standards and Requirements. Version 30 October, 2005. ASPHER. Available from URL: http://www.aspher.org/pliki/ pdf/accreditation_of_european_public_health_education_standards_and_ requirements.pdf (Accessed 14 September, 2011).

7. Goodman J, Overall J, Tulchinsky T. Public Health Workforce Capacity Building: Lessons Learned from Quality Development of Public Health Teaching Programmes in Central and Eastern Europe. ASPHER Publication \#3. April 2008.

8. Overall JW, Goodman J. The role of non-governmental organizations in development of schools of public health: an example from Eastern Europe and Central Asia. Public Health Reviews. 2011;33:168-89.

9. Adany R, Villerusa A, Bislimovska J, Kulzhanov M. Public health education in Central and Eastern Europe, and Central Asia. Public Health Reviews. 2011;33:105-33.

10. Gudmann A, Holstein B, Krasnik A. The European Accreditation Agency for Public Health Education (EAAPHE). Working Package 5 Report. EU Leonardo da Vinci Programme. January 2008. Available from URL: http:// www.aspher.org/pliki/pdf/WP5_Report.pdf (Accessed 14 September, 2011).

11. Chauvigné C, Ottenwaelter MO. Mapping and analysis of quality assurance and accreditation systems in public health education. Working package 2 report. EU Leonardo da Vinci Programme. November 2006. Available from URL: http://www.aspher.org/pliki/pdf/WP2_Report.pdf (Accessed 14 September, 2011).

12. Association of Schools of Public Health in the European Region. Provisional List of Core Competencies for MPH Education. Draft for comments. Version 11 March, 2011. ASPHER. Available from URL: http://www.aspher.org/ pliki/pdf/Competencies_for_MPH_education_110311.pdf (Accessed 14 September, 2011).

13. Birt CA, Foldspang A. The developing role of systems of competences in public health education and practice. Public Health Reviews. 2011;33:134-47.

14. The European Agency for Accreditation in Public Health Education. Eligibility criteria. June 2011. 